\section{Starch Gel Electrophoresis of Basic Water-Soluble Barley Grain Proteins}

TOR-MAGNUS ENARI, JUHANI MIKOLA, and MARTTI N UMMI

\section{Laboratory of Brewing, Helsinki, Finland}

W e have earlier reported the fractionation of water-soluble proteins of barley grain by ion-exchange chromatography on DEAE-cellulose ${ }^{1,2}$. The basic proteins (about $30 \%$ of the total) passed unretarded through the column in $5 \mathrm{mM}$ phosphate buffer of pH 7.5 and the neutral and acid proteins were resolved into $\mathbf{1 5}$ components with gradient elution.

The basic protein fraction gives four components on paper electrophoresis at pH 8.6 (Fig. 1). These are apparently iden-

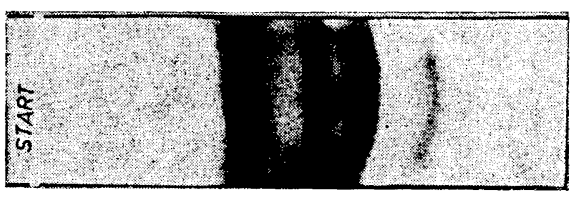

Fig. 1. Paper electrophoresis at $\mathrm{pH} 8.6$ of basic barley proteins.

tical with the four cathodic components which we have found in the paper electrophoresis of unfractionated barley extracts ${ }^{3}$. Apparently they correspond to the three cathodic fractions which Mourgue and his collaborators have found in the paper electrophoresis of Ricinus ${ }^{4}$ and Jatropha ${ }^{5}$ seed extracts.

We have developed a preparative method for the purification of the basic proteins and resolved the material obtained into two anodic and fourteen cathodic components bystarch-gel electrophoresis at $\mathrm{pH} 8.4$.
Preparation of basic proteins. $500 \mathrm{~g}$ of finely ground and acetone treated barley (Pirkka) was extracted for $2 \mathrm{~h}$ with $1000 \mathrm{ml}$ of water ${ }^{\circ}$ with occasional stirring at $4^{\circ} \mathrm{C}$. The slurry was centrifuged at 5000 r.p.m. for $10 \mathrm{~min}$ and the extract was left standing at $4^{\circ} \mathrm{C}$ for two days. During this period most of the phytic acid and watersoluble polysaccharides are hydrolyzed ?. The small precipitate which forms on standing was removed by centrifugation. The proteins were then separated from interfering small-molecular substances and simultaneously transferred to $5 \mathrm{mM}$ sodium phosphate buffer of $\mathrm{pH} 7.5$ by gel filtration on Sephadex G-25 equilibrated with this buffer. The solution obtained was run through a $20 \mathrm{~g}$ preparative column of DEAE-cellulose (Schleicher \& Schüll), equilibrated with the $5 \mathrm{mM}$ buffer, to remove neutral and acid proteins. The solution containing the unretarded basic proteins and polysaccharides was acidified to $\mathrm{pH} 4.5$ and made $0.1 \mathrm{M}$ in respect to acetate with cautious addition of $1 \mathrm{M}$ acetic acid and sodium acetate. The proteins were absorbed on a $20 \mathrm{~g}$ column of CM-cellulose (Schleicher \& Schüll) at pH 4.5 and, after washing with the starting buffer, eluted with $0.3 \mathrm{M}$ sodium phosphate $\mathrm{pH}$ 8.0. The sodium phosphate was removed from the proteins by gel filtration on Sephadex G-25 equilibrated with a $10 \mathrm{mM}$ ammonium formate buffer. The volatile salt was required to suppress the ion-exchange properties of Sephadex G-25. After lyophilization the basic proteins weighed about $700 \mathrm{mg} .60-80 \mathrm{mg}$ of this dry protein material was dissolved in $0.5 \mathrm{ml}$ of water and this solution was used for electrophoretic analyses.

Electrophoretic conditions. The electrophoretic separation was performed by the vertical method described by Smithies ${ }^{8}$, with minor alterations. The gels were prepared in plastic trays $30 \times 12 \times 0.6 \mathrm{~cm}$ from starch supplied by Connaught Medical Research Laboratories, Toronto. The starch was used at a concentration of $11.3 \mathrm{~g} / 100 \mathrm{ml}$ of buffer solution (for

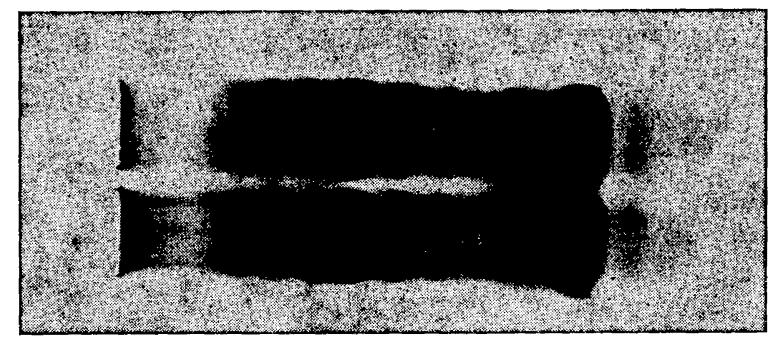

Fig. 2. Starch gel electrophoresis at pH 8.4 of basic barley proteins.

Acta Chem. Scand. 16 (1962) No. 2 
serum $12.3 \mathrm{~g} / 100 \mathrm{ml}$ was recommended). The buffer for gels contained 0.026 mole of $\mathrm{H}_{3} \mathrm{BO}_{3}$ and 0.014 mole of $\mathrm{NaOH}$ per litre, giving a final $\mathrm{pH}$ of 8.4 in the settled gel. The bridge solution contained 0.2 mole of $\mathrm{H}_{3} \mathrm{BO}_{3}$ and 0.04 mole of $\mathrm{NaOH}$ per litre. The potential gradient employed was $10 \mathrm{~V} / \mathrm{cm}$ the positive electrode being in the upper vessel and the basic proteins migrating downwards to the cathode. All runs were made at $4^{\circ} \mathrm{C}$. The cut gels were stained for $10 \mathrm{~min}$. with Amido Black $B$ and washed 4-5 times.

Results. The result obtained is shown in Fig. 2, in which 14 cathodic zones can be seen. On the anodic side there is one very diffuse region and one strongly stained band near the start which apparently corresponds to the least basic of the four bands in paper electrophoresis. At $\mathrm{pH}$ 7 all the protein material migrated towards the cathode. Thus the two anodic bands at $\mathrm{pH} 8.4$ can also be considered to be basic proteins.

Under the conditions described here, the basic fraction of water-soluble barley grain proteins can be resolved reproducibly into 16 bands of significant intensity, which appear to be native components of barley grain.

Acknowledgements. The investigation has been supported by a grant from the Finnish State Commission of Natural Sciences (Valtion Luonnontieteellinen Toimikunta) which is gra. tefully acknowledged. The authors are indebted to Mrs. Ritva Korhonen and Mr. E. Nikkola for skilful technical assistance.

1. Enari, T.-M. and Mikola, J. Suomen Kemistilehti B 33 (1960) 206.

2. Enari, T.-M. and Mikola, J. European Brewery Conv. Proc. 8th Congr. Wien 1961. In press.

3. Enari, T.-M., Nummi, M. and Mikola, J. 5th Intern. Congr. Biochem. Moscow 1961. In press.

4. Mourgue, M., Baret, R., Reynaud, J. and Bellini, J. Bull. soc. chim. biol. 40 (1958) 1453.

5. Mourgue, R., Baret, R., Kassab, R. and Reynaud, J. Bull. soc. chim. biol. 43 (1961) 505 .

6. Enari, T.-M., Nummi, M., Mikola, J. and Mäkinen, V. Finska Kemistsamfundets Medd. 71 (1962) In press.

7. Mikola, J., Nummi, M. and Enari, T.-M. In press.

8. Smithies, O. Biochem. J. 71 (1959) 585.

Received January 30, 1962.

\section{A Lignan Xyloside from the Sap- wood of Sorbus aucuparia $L$.}

V.P. A R Y A, H. ER D T MAN,

M. KROLIEOW BAA and T. NORIN

Institutionen för Organisk Kemi, Kungl. Tek. niska Högskolan, Stockholm 70, Sweden

$T^{\mathrm{s}}$ he isolation of two biphenyl derivatives of unusual structure, aucuparin and methoxyaucuparin from the heartwood of mountain ash (Sorbus aucuparia L.) has recently been reported from thislaboratory. The sapwood contains a lignan xyloside $(1-3 \%$ of the dry wood). This xyloside is identical with the lignan xyloside from Alnus glutinosa ${ }^{2}$ and a Lyonia species as shown by a comparison of the physical constants recorded in Table 1 .

The investigation of the Alnus xyloside showed that the aglycone has the structure $\mathrm{I}(\mathrm{X}=\mathrm{H})$.

The Sorbus aglycone was obtained by the hydrolysis of the xyloside with acid as well as emulsin. This observation and the small difference in optical rotation between the xyloside and the aglycone indicates that the xyloside is a $\beta$-xyloside. Permanganate oxidation of the aglycone dimethyl ether in acetone afforded galloylgallic acid hexamethyl ether, m.p. $190-191^{\circ}$, and gallic acid trimethyl ether. Mild oxidation of the aglycone dimethyl ether with chromic anhydride in pyridine gave a lactone ("' $a$ lactone"), $\mathrm{C}_{18} \mathrm{H}_{10} \mathrm{O}_{2}\left(\mathrm{OCH}_{3}\right)_{6}, \quad$ m.p. $200-$ $201^{\circ},[\alpha]_{D}-103^{\circ}(\mathrm{a}),-122^{\circ}$ (c) and a cyclohemiacetal, $\mathrm{C}_{18} \mathrm{H}_{11} \mathrm{O}(\mathrm{OH})\left(\mathrm{OCH}_{3}\right)_{0}$, m.p. $180-181^{\circ},[a]_{D}-6^{\circ}$ (c) [monoacetat $\theta$, $\mathrm{C}_{18} \mathrm{H}_{11} \mathrm{O}$ (OAc) $\left(\mathrm{OCH}_{3}\right)_{6}$, m.p. $158-160^{\circ}$, $\left.[a]_{\mathrm{D}}-13^{\circ}(\mathrm{c})\right]$ which on further oxidation furnished the $\alpha$-lactone. The $a$-lactone gave the aglycone dimethyl ether on reduction with lithium aluminium hydride. On dehydration with potassium hydrogen sulphate the latter aglycone derivative afforded the anhydro-compound, $\mathrm{C}_{18} \mathrm{H}_{10} \mathrm{O}$ $\left(\mathrm{OCH}_{3}\right)_{6}$, m.p. $145-146^{\circ},[\alpha]_{\mathrm{D}}-41.6^{\circ}$ (a) as does the Alnus aglycone dimethyl ether

The Sorbus xyloside dimethyl ether was oxidised with chromic anhydride in pyridine to an amorphous acid which on hydrolysis furnished the Sorbus "a-lactone". The sugar residue must be attached to the methylol group not suffering oxidation and the problem of elucidating the structure of the xyloside is therefore reduced to a determination of the structure of the $\alpha$-lactone. 